MRC

For Sustainable Development

${ }_{s / N_{A B L E D E} V V^{O}}$

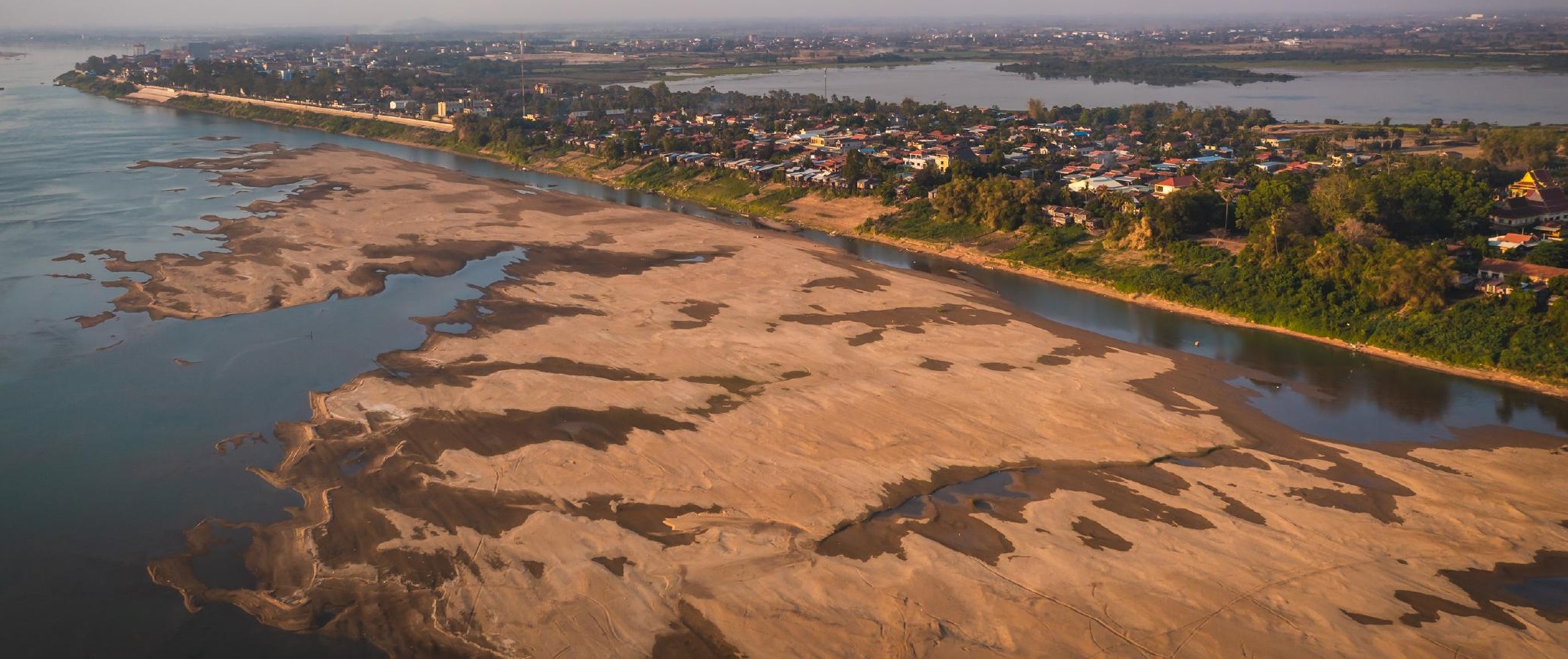

Situation Report

\title{
Dry Season Hydrological Conditions in the Lower Mekong River Basin: November 2020-May 2021
}


The MRC is funded by contributions from its Member Countries and Development Partners, including Australia, Belgium, the European Union, Flanders/Belgium, France, Germany, Japan, Luxembourg, the Netherlands, Sweden, Switzerland, United States of America, and the World Bank. 


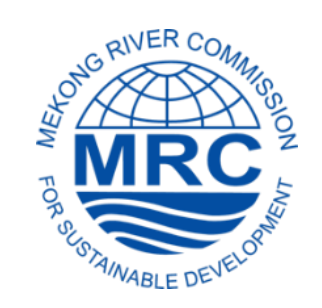

Situation Report

\section{Dry Season Hydrological Conditions in the Lower Mekong River Basin: \\ November 2020-May 2021}




\section{Copyright (c) Mekong River Commission, 2021}

First published (2020)

Some rights reserved

This work is the product of the Mekong River Commission Secretariat. While all efforts are made to present accurate information, the Secretariat does not guarantee the accuracy of the data included in this work. The boundaries, colours, denomination, and other information shown on any map in this work do not imply any judgement on the part of the MRC concerning the legal status of any territory or the endorsement or acceptance of such boundaries.

Nothing herein shall constitute or be considered to be a limitation upon or waiver of the privileges and immunities of the MRC, all of which are specifically reserved.

This publication may be reproduced in whole or in part and in any form for educational or non-profit purposes without special permission from the copyright holder, provided acknowledgement of the source is made and notification is sent to the MRC. The MRC would appreciate receiving a copy of any publication that uses this publication as a source. This publication cannot be used for sale or for any other commercial purpose whatsoever without permission in writing from the MRC.

Title: Situation report on hydrological conditions in the Lower Mekong River Basin: November 2020May 2021

ISSN: $1683-1489$

Keywords: drought/precipitation/ENSO/water level

For bibliographic purposes, this volume may be cited as:

Mekong River Commission. (2021). Situation report on dry season hydrological conditions in the Lower Mekong River Basin: November 2020-May 2021. Vientiane, MRC Secretariat.

Information on MRC publications and digital products can be found at www.mrcmekong.org/ publications

All queries on rights and licences should be addressed to:

Mekong River Commission

Documentation and Learning Centre

184 Fa Ngoum Road, Unit 18, Ban Sithane Neua, Sikhottabong District, Vientiane 01000, Lao PDR

Telephone: +856-21 263263 | E-mail: mrcs@mrcmekong.org | www.mrcmekong.org 


\section{Contents}

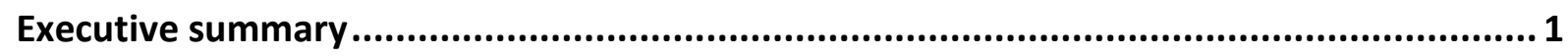

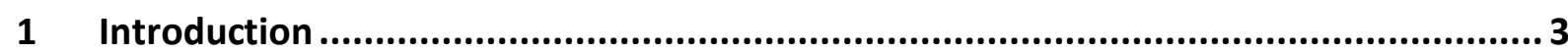

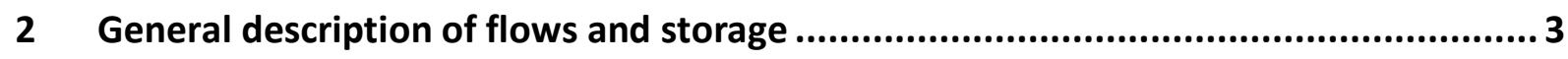

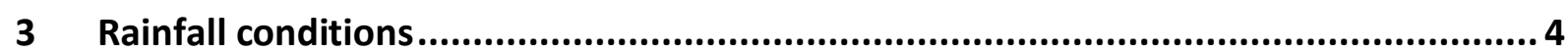

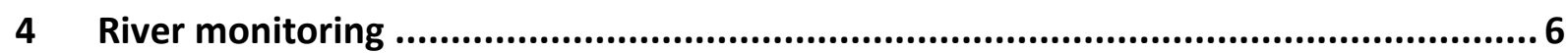

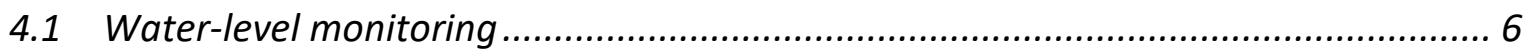

4.2 Water-level fluctuation in the dry season .................................................................. 7

4.3 Water volumes of the Tonle Sap Lake ................................................................. 9

5 Drought monitoring................................................................................................. 10

6 Outlook for the 2021 early wet season............................................................... 12

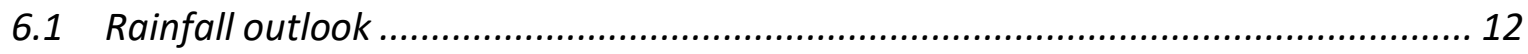

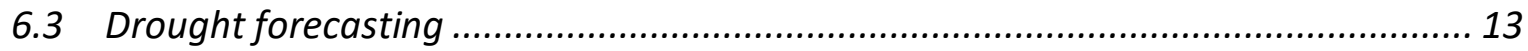

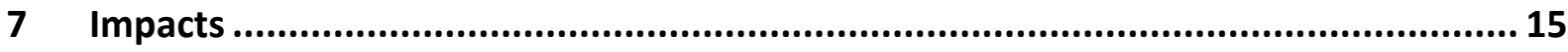

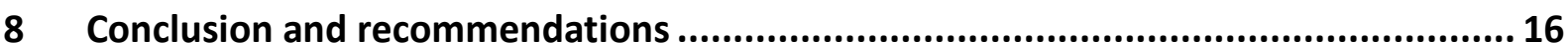

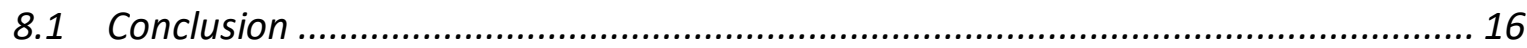

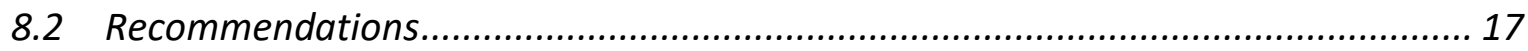

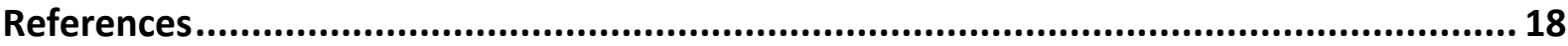




\section{Figures}

Figure 1. The accumulated rainfall in the Mekong River Basin from January to May, compared with 2019, 2020 and the long-term average.......................................................... 4

Figure 2. Map of spatial rainfall $(\mathrm{mm})$ for the 2020-2021 dry season .................................. 5

Figure 3. Dry Season Water Level Monitoring at main stations in the Mekong River and in the Tonle Sap Lake (Prek Kdam) for the 2021 dry season ............................................. 6

Figure 4. Daily water level at the Jinghong hydrological station 1 Jan.-31 May 2021 ............ 7

Figure 5. Propagation of daily water level at the main stations for the dry season 2020-2021

Figure 6. Characteristic of water-level fluctuation at Chiang Saen and Chiang Khan stations for 2020-2021 dry season

Figure 7. Monthly water storage in the Tonle Sap Lake for the 2021 dry season ................... 10

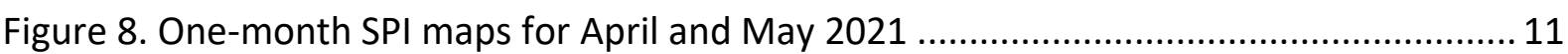

Figure 9 Three-month SPI maps for Jan.-Feb.-Mar (left), Feb.-Mar.-Apr (middle), and Mar.Apr.-May (right) 2021.

Figure 10. Monthly total precipitation anomaly in June, July and August 2021 in Asia

Figure 11. Outlook of the SST deviation and ENSO forecast probabilities up to September 2021

Figure 12. The early wet season (June, July, and August) forecast of precipitation (left) and temperature (right)

Figure 13. The Standardized Precipitation Index forecast for June, July, August and September 2021

Figure 14. The forecasted Combined Drought Index (CDI) for June and July 2021 14 


\section{Acronyms and abbreviations}

$\begin{array}{ll}\text { ENSO } & \text { El Niño Southern Oscillation } \\ \text { LMB } & \text { Lower Mekong River Basin } \\ \text { LTA } & \text { Long-term average } \\ \text { NMC } & \text { National Mekong Committee } \\ \text { MRC } & \text { Mekong River Commission } \\ \text { MC } & \text { Member Country } \\ \text { PMFM } & \text { Procedures for the Maintenance of Flows on the Mainstream } \\ \text { SPI } & \text { Standardized Precipitation Index }\end{array}$




\section{Executive summary}

This Situation Report presents a preliminary analysis of the Lower Mekong River Basin (LMB) hydro-meteorological conditions over the 2020-2021 dry season, spanning November 2020May 2021 (i.e. the 2021 dry season). The overall conditions are summarized below.

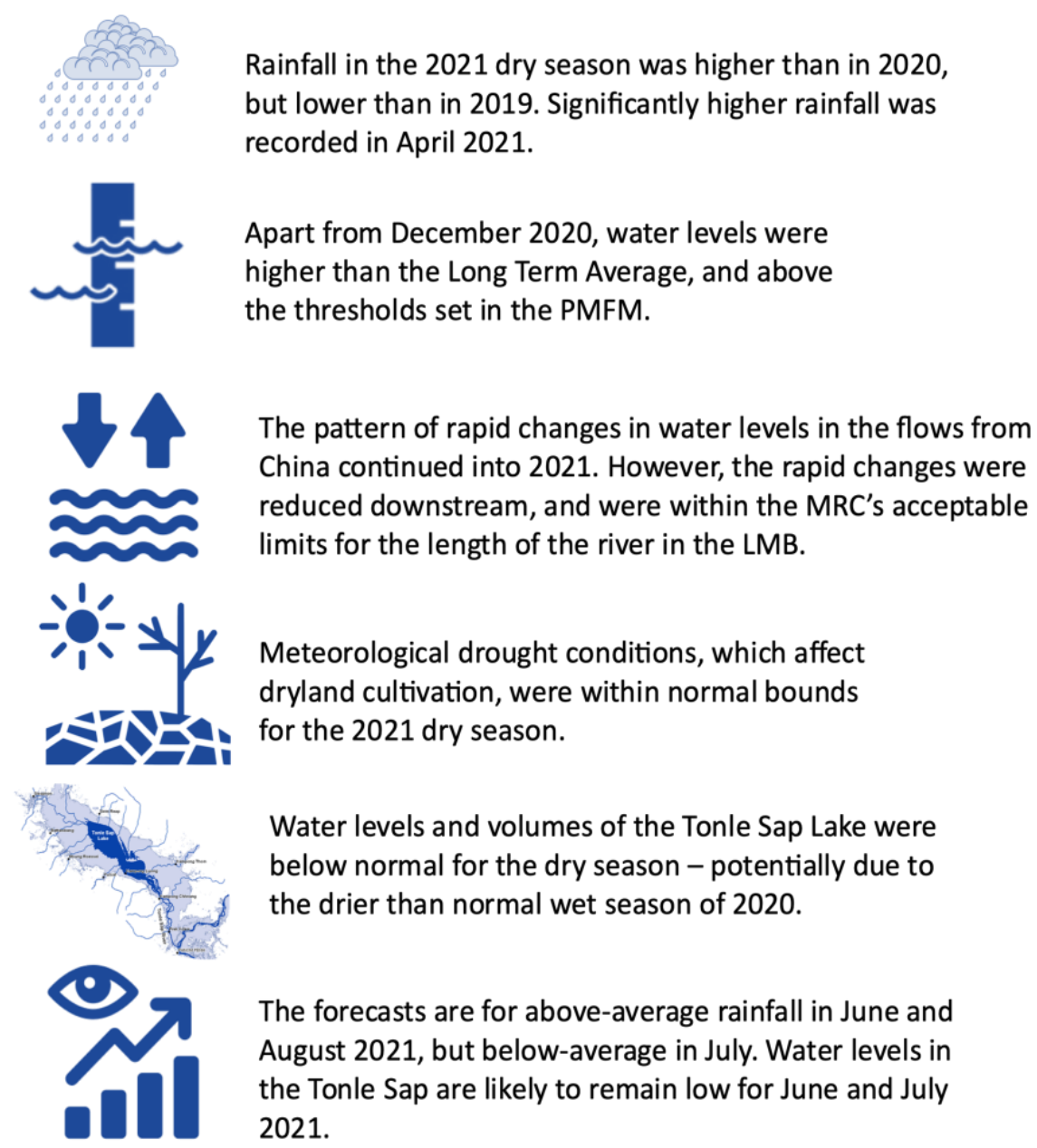

The 2021 accumulated rainfall follows the long-term average (LTA), higher than 2019 and 2020, particularly for the last two months. The water levels of the Mekong River were lower than their LTAs for all monitoring stations for November and December 2020, and January 2021. But they were higher than the LTAs for February-May 2021, and thus compliant with agreed dry season thresholds according to the MRC Procedures for the Maintenance of Flows on the Mainstream (PMFM) for monitoring ${ }^{1}$. For the Mekong Delta in Viet Nam at Tan Chau and Chau Doc, the fluctuation levels have been out of the historical range between maximum and minimum levels for almost six months. However, this may be due to exceptional spring and neap tidal effects due to the closeness of the moon, and potentially higher sea levels.

\footnotetext{
${ }^{1}$ The MRC PMFM is available for public access. See MRC (2006, 2021b).
} 
The Jinghong hydrological station experienced rapid fluctuations lasting several days. The water level at Chiang Saen and Chiang Khan is less variable as the flow peaks attenuate downstream. The maximum rate of water-level change at these two sites was less than $0.5 \mathrm{~m} /$ day, which is considered "not significant" according to the MRC Hydropower Guideline for Aquatic Ecology and Geomorphology. But this may cause problems for navigation along narrower stretches of the river where fluctuations would be more observable.

The Tonle Sap Lake experienced extremely dry conditions. The water volumes of the Lake were higher than in 2020 and closer to the 2019 volumes (both of which were drought years) but lower than in 2018 over the same period. The Lake's water volume for this dry season is considered low compared to the LTA levels.

The rainfall and river flow during the 2021 dry season were at normal levels. The meteorological indicator shows some moderate and severe dryness in the lower part of the LMB, covering some northern part of Cambodia and Central Highland of Viet Nam.

Forecasts suggest that the LMB is likely to receive above-average rainfall in June and August but below-average rainfall in July. The low levels in the Tonle Sap Lake in May will continue into June and July as the tributary dams fill up as the rain starts. The reverse flow to the Tonle Sap Lake, which usually starts in mid-May, is consequently expected to follow the previous year's pattern but is still subject to actual rainfall over LMB from June to October 2021.

Transparent and timely data and information sharing and exchange remain critical. The Mekong River Commission Secretariat (MRCS) continues to identify additional key data and information necessary for water resource management and development. Additional efforts in data and information sharing and exchange by the MRC Member Countries (MCs) and Dialogue Partners are highly encouraged. Prior notification of planned operations along the Lancang Cascade will help alleviate potential navigation problems. 


\section{Introduction}

The Mekong River Commission (MRC) is an intergovernmental organization for regional dialogue and cooperation in the lower Mekong River basin. It was established in 1995 per Chapter IV of the Mekong Agreement between Cambodia, Lao PDR, Thailand, and Viet Nam. The organisation serves as a regional platform for water diplomacy and a knowledge hub of water resources management for the region's sustainable development. The Mekong River and its tributaries support over 65 million people in the LMB, providing livelihoods, food security and ecosystem services.

One of the MRC's core functions is to monitor and report on basin conditions, it is therefore essential to regularly update the MCs and the public regarding the hydro-meteorological situation in the basin. This includes information on possible causes and the status of the flow in the river. The MRC also suggests measures that could be taken to minimize or mitigate the associated environmental, social, and economic impacts.

Therefore, this Situation Report for the 2020-2021 dry season presents a preliminary analysis of the general hydro-meteorological conditions in the LMB over seven months over the dry season from November 2020 to May 2021 and the outlook for the wet season 2021. The report covers the rainfall conditions, river water-level fluctuations, drought monitoring.

\section{General description of flows and storage}

The dry season is defined by the MRC as from 1 November to 31 May, and the wet season from 1 June to 30 October, each year. The Lower Mekong Basin has seen considerable growth in water storage behind hydropower dams over the last decade this affects the natural hydrology in the following ways.

- Under natural conditions, river flows at the end of the wet season taper off gradually as the rainfall became more sporadic and patchier.

- With additional storage, the flows drop off more precipitously as soon as the storage drops below the full supply level in each reservoir. If the wet season has been drier than normal, this results in lower-than-normal flows in November and December, depending on when the rain stops.

- During the rest of the dry season, water released through hydropower turbines to provide assured power to drive the regional economy, maintains higher than normal flows.

- At the start of the wet season, the first flows are used to fill the storage, and flows in the mainstream pick up later than normal. This delays the return flow into the Tonle Sap Lake, with consequent impacts on fisheries production and recession agriculture.

- The Tonle Sap Lake is a natural storage, keeping flows into the Delta higher at the start of the dry season. Below normal rainfall means that the Tonle Sap Lake does not fill up as much, and it has less of a natural regulatory impact on flows into the Delta.

- Outside of China, the mainstream hydropower dams have little storage and have little effect on the overall flow regime. However, they may cause flows to vary over the daily 
cycle if they are operated to respond to the fluctuating regional power demands. This has considerable impacts on the aquatic ecology just downstream of the station.

These effects are multiplied when the wet season is shorter and drier than normal.

\section{Rainfall conditions}

The 2021 accumulated rainfall follows the LTA. Rainfall was higher than in 2019 and 2020, particularly for the last two months (Figure 1).

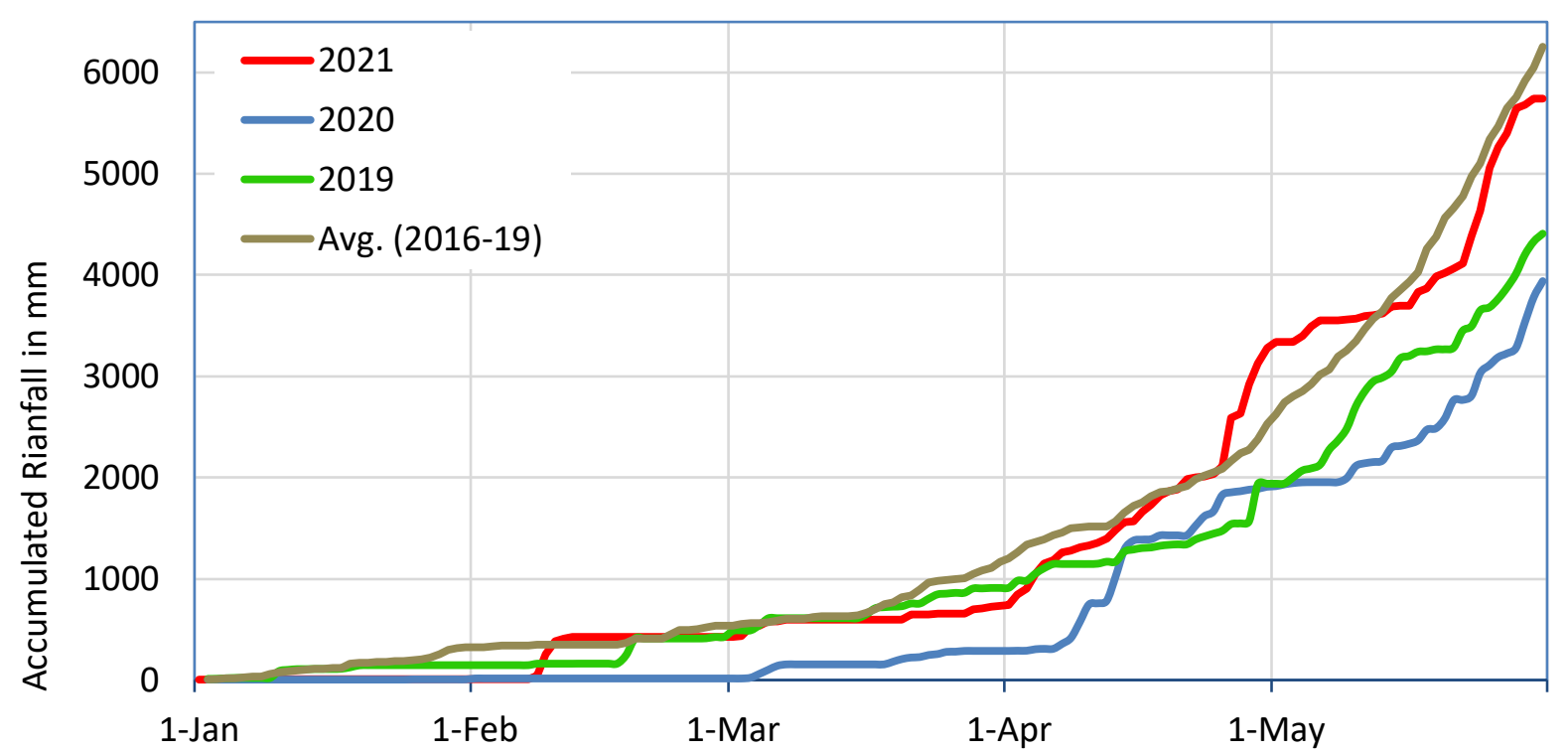

Figure 1. The accumulated rainfall in the Mekong River Basin from January to May, compared with 2019, 2020 and the long-term average

The rainfall in this dry season was mainly from convective clouds created by localised rising hot air. The 2020 wet season southwest monsoon wind had disappeared before the dry season. The northeast monsoon wind had become weak so that the localised hot spots and convective clouds prevailed. The spatial rainfall maps showed a sporadic, uneven distribution of rainfall over the LMB (Figure 2). This is often associated with strong winds and thunderstorms. 

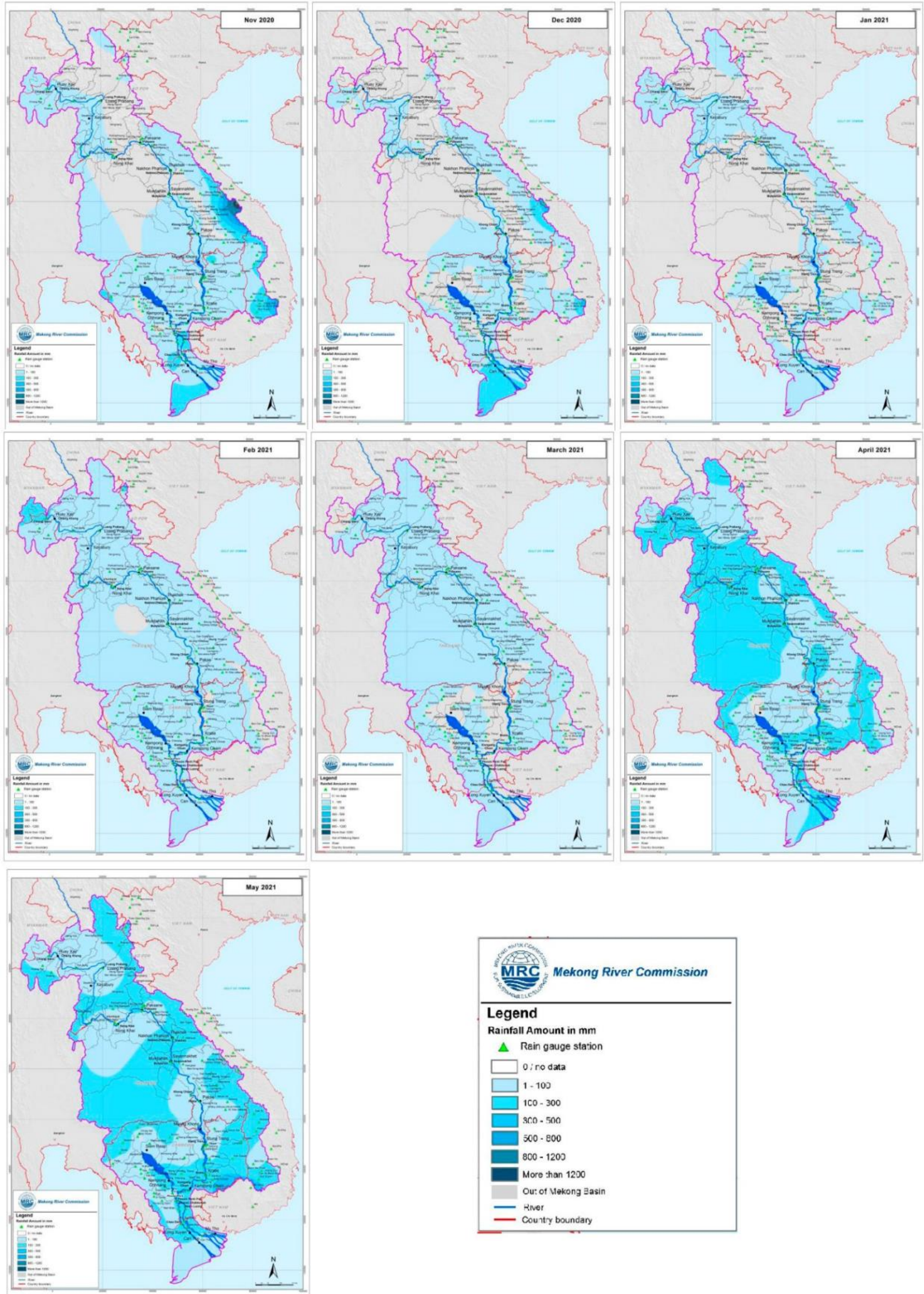

Figure 2. Map of spatial rainfall $(\mathrm{mm})$ for the 2020-2021 dry season 


\section{$4 \quad$ River monitoring}

\subsection{Water-level monitoring}

The hydrological regimes of the Mekong mainstream are tracked by water-level gauging at many points on the mainstream and tributaries. The Chiang Saen station captures mainstream flows from the Upper Mekong Basin (UMB) in China. The Vientiane station represents flows generated by climate conditions in the upper part of the LMB. Pakse indicates the flows influenced by inflows from the larger Mekong tributaries and the tributary dam operations. The Kratie station in Cambodia captures the overall flows of the Mekong Basin, and Viet Nam's Tan Chau and Chau Doc stations show the flows into the Delta (when the tidal effects are removed).

The actual water levels for January to May 2021 at Chiang Saen, Vientiane, Pakse, Kratie, Prek Kdam (Tonle Sap River), and Tan Chau (Mekong Delta) are shown and compared to the historical data (Figure 3). The water levels in the Mekong River were higher than their LTAs for most of the dry season at all monitoring stations, except for the tidal stations at Viet Nam's Tan Chau due to daily tidal effects from the sea. The tidal affected station showed water levels fluctuating out of the normal long-term range between maximum and minimum during February and March. It is probably because of the spring and neap tidal effects that occur at different times each year (being on a 28-day cycle rather than a monthly one), by the changing distance between the earth and moon, and potentially from higher sea levels. The water level and flow conditions were above the minimum flow thresholds established in the PMFM, except in December 2020. This was likely due to below-normal rainfall in the 2020 wet season.
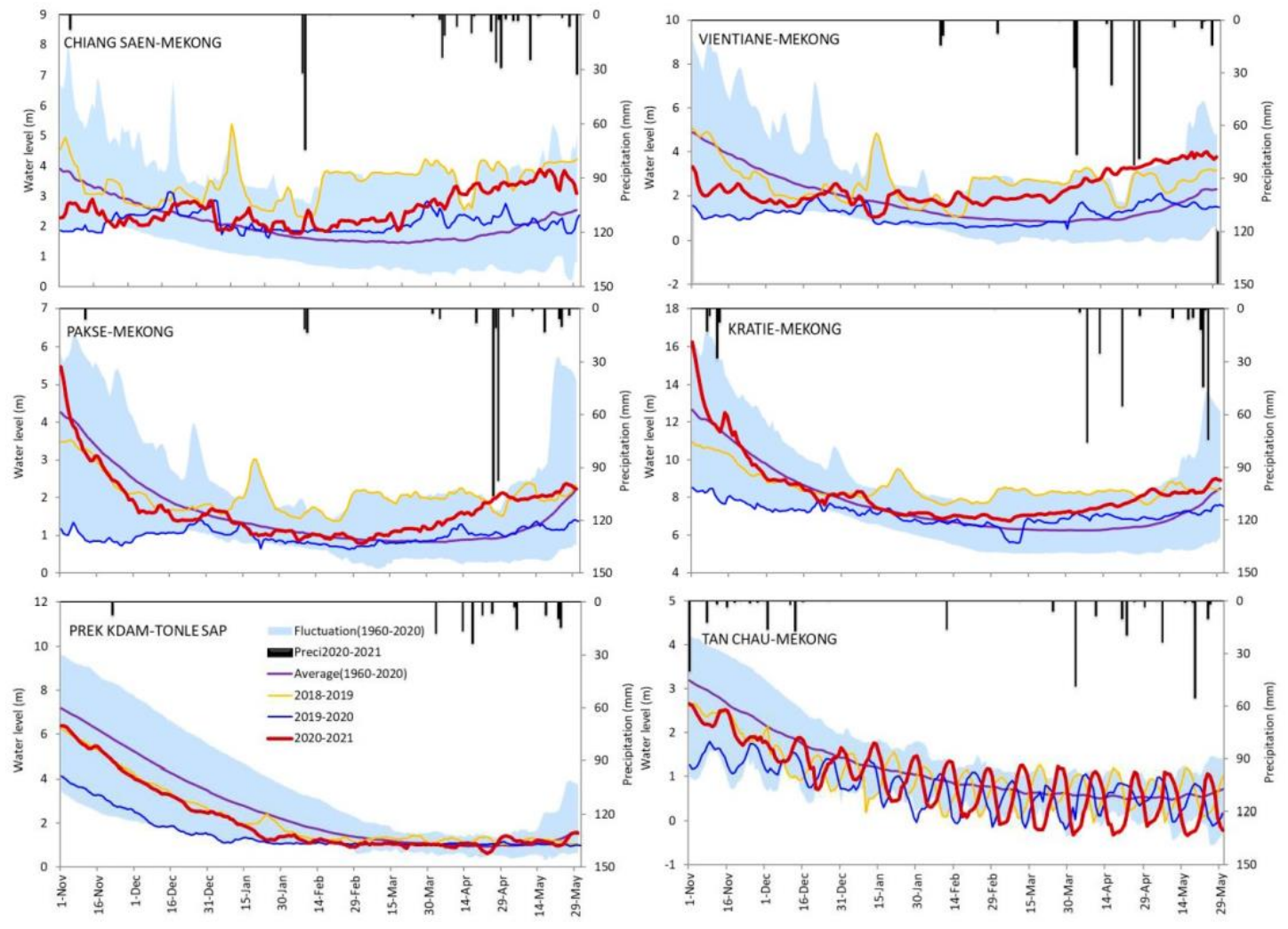

Figure 3. Dry Season Water Level Monitoring at main stations in the Mekong River and in the Tonle Sap Lake (Prek Kdam) for the 2021 dry season 


\subsection{Water-level fluctuation in the dry season}

An initial assessment was carried out to investigate the water-level fluctuation for this dry season. The water-level fluctuation observed at Chiang Sean reflects the Lancang Cascade Dam Operation.

According to MRC's observed water-level data, the water levels at the Jinghong hydrological station fluctuated between 1 January and 31 May 2021 (Figure 4). The station's water level dropped from $536.74 \mathrm{~m}$ on 15 January to $535.43 \mathrm{~m}$ on 23 January (i.e. $1.3 \mathrm{~m}$ over eight days). It continued to significantly fluctuate through the rest of the dry season, dropping from 538.29 $\mathrm{m}$ on 14 May to $536.96 \mathrm{~m}$ on 31 May (1.33 m drop).

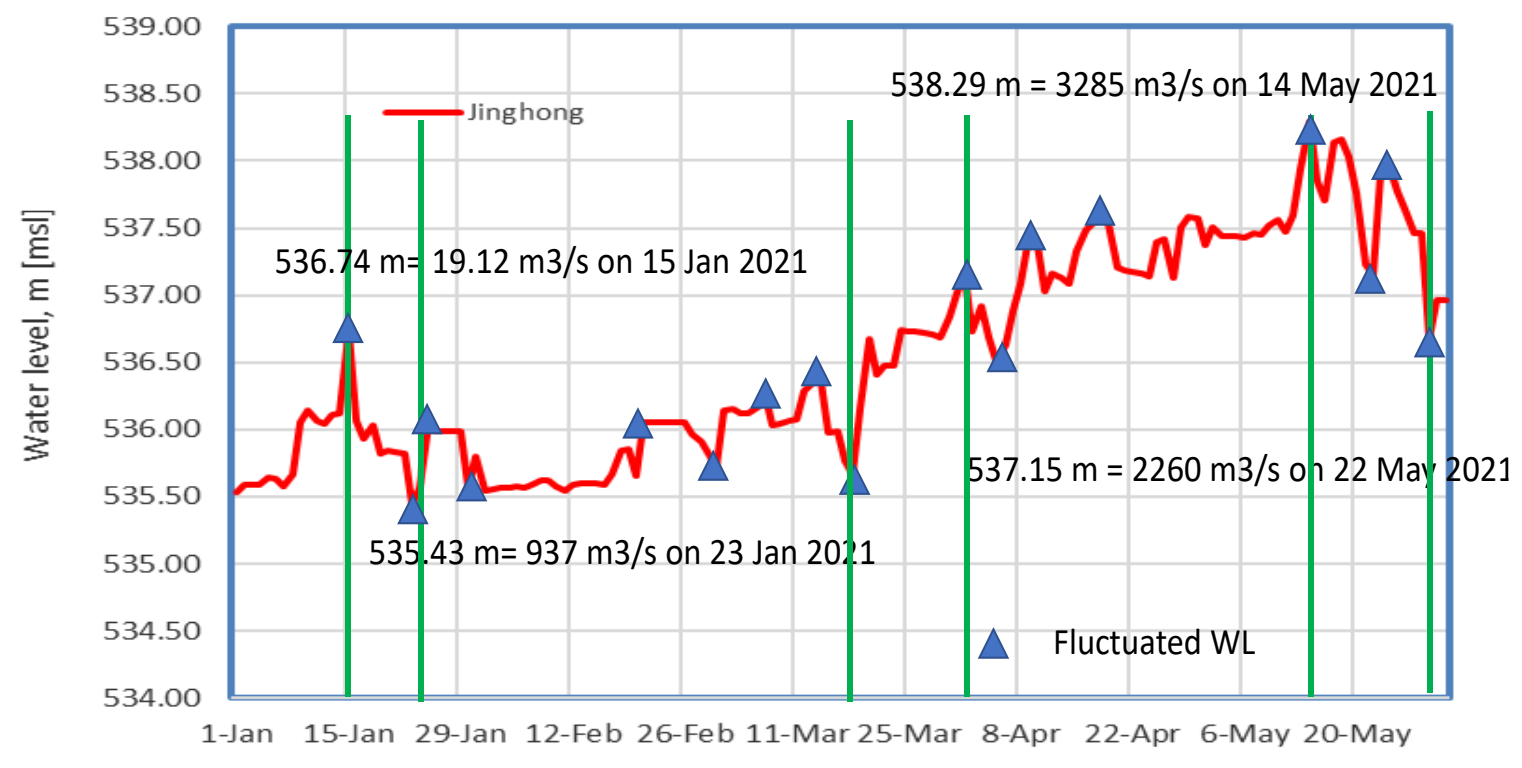

Figure 4. Daily water level at the Jinghong hydrological station 1 Jan.-31 May 2021

This has been typical of the flows out of China since dams on the Lancang cascade became operational. This has caused problems for navigation in 2013, 2015 and 2018, as reported in the Bangkok Post. No similar reports were evident in this dry season.

The fluctuations in observed water levels at Chiang Saen follow the trend in Jinghong (Figure 5). But the water-level pattern has fluctuated less since the Chiang Saen is about $330 \mathrm{~km}$ from Jinghong station.

The water levels at the Luang Prabang station are affected by the backwater caused by Xayaburi Dam (Figure 5). The water levels at Chiang Khan, Vientiane and Nong Khai reflect the river conditions impacted to some extent (albeit less noticeably) by operations on Lancang Cascade and the Xayaburi Hydropower Project. Since these stations are farther downstream, the fluctuations in water levels become less noticeable. 


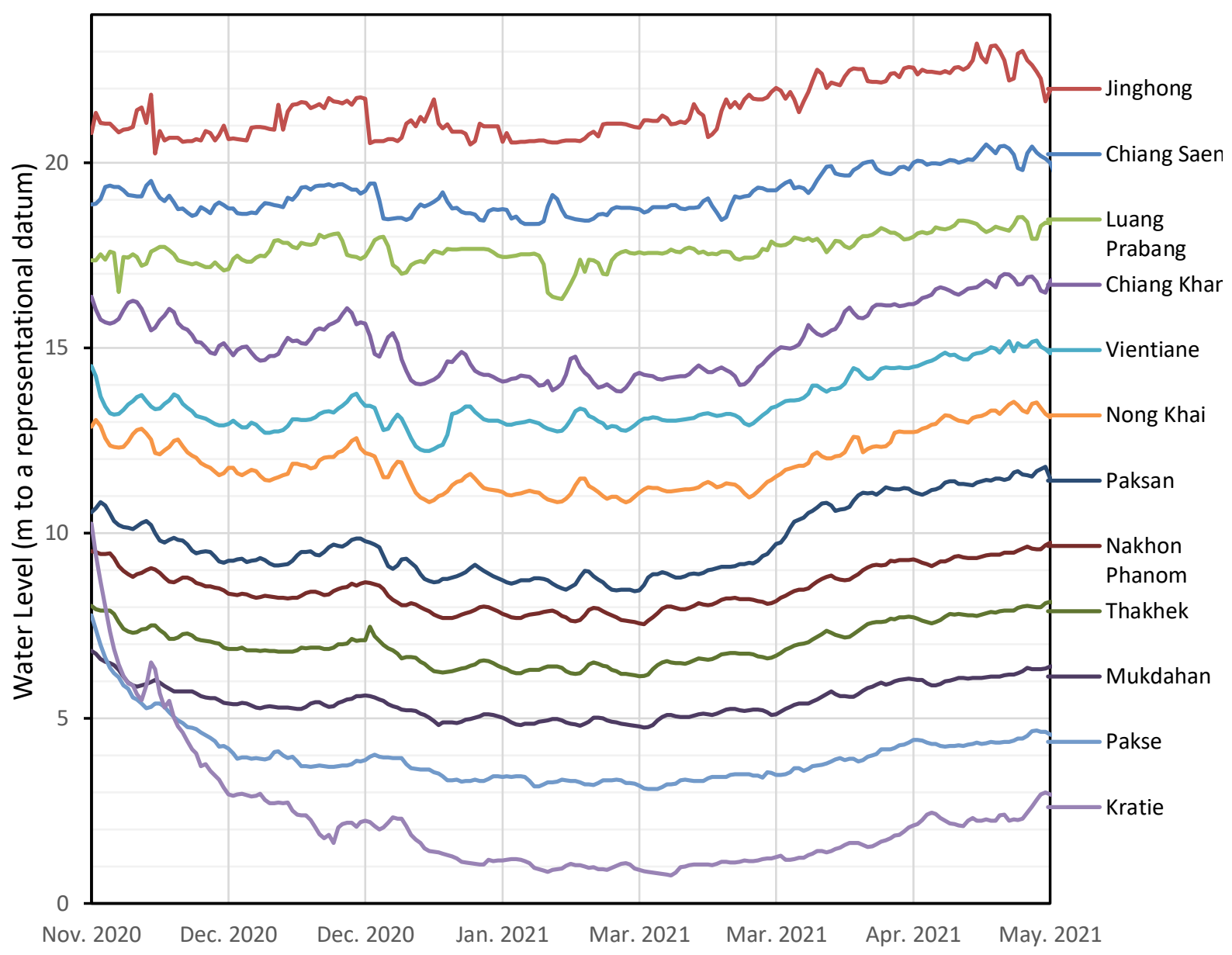

Figure 5. Propagation of daily water level at the main stations for the dry season 2020-2021

Based on the 15 min telemetry data, Chiang Saen station did not show short-term water-level fluctuation in the dry season 2020-2021. This is because of the distance (about $330 \mathrm{~km}$ ) from the Langcang Cascade Dams, and because the river becomes wider $(530 \mathrm{~m})$. The water-level fluctuations (decreases and increases) at the Chiang Saen station averaged at about $0.1 \mathrm{~m} /$ day. It had higher water-level fluctuations in November 2020, and January, February and May 2021 (Figure 6). The highest water-level increase (0.48 m/day) was in January 2021.

However, overall decreases in water levels in both January and February 2021 were noted. At the end of May 2021, there was another major drop in water levels $(0.46 \mathrm{~m} /$ day) was noted. However, the maximum rate of water-level change is still less than $0.5 \mathrm{~m} /$ day. According to the MRC Hydropower Mitigation Guideline (MRC, 2020), this water-level change is considered not significant. In other words, the fluctuation of less than $5 \mathrm{~cm} / \mathrm{hr}$ is considered acceptable.

The Chiang Khan station is about $230 \mathrm{~km}$ downstream from the Xayaburi Hydropower Dam. This station has a similar average rate of water-level change as Chiang Saen. In November 2020 and in January, February, and May 2021, it had a high magnitude of water fluctuation (Figure $5)$. The highest water-level increase ( $0.48 \mathrm{~m} /$ day) occurred in January 2021 , while the maximum water-level drop ( $0.43 \mathrm{~m} /$ day) was observed in February 2021. However, the highest rate of water-level fluctuation was still less than $0.5 \mathrm{~m} /$ day. 
Nonetheless, the two stations (Chiang Saen and Chiang Khan stations) are far downstream of the dam sites. However, the Ban Pakhoung station just downstream of the Xayaburi Dam did show evidence of rapid daily fluctuations in water levels in December and January as power output was varied according to demands. These changes in water levels will be analysed as part of a future study with a more detailed assessment of water levels at the Ban Pakhoung station and the new station at Xiengkok upstream of Chiang Saen.
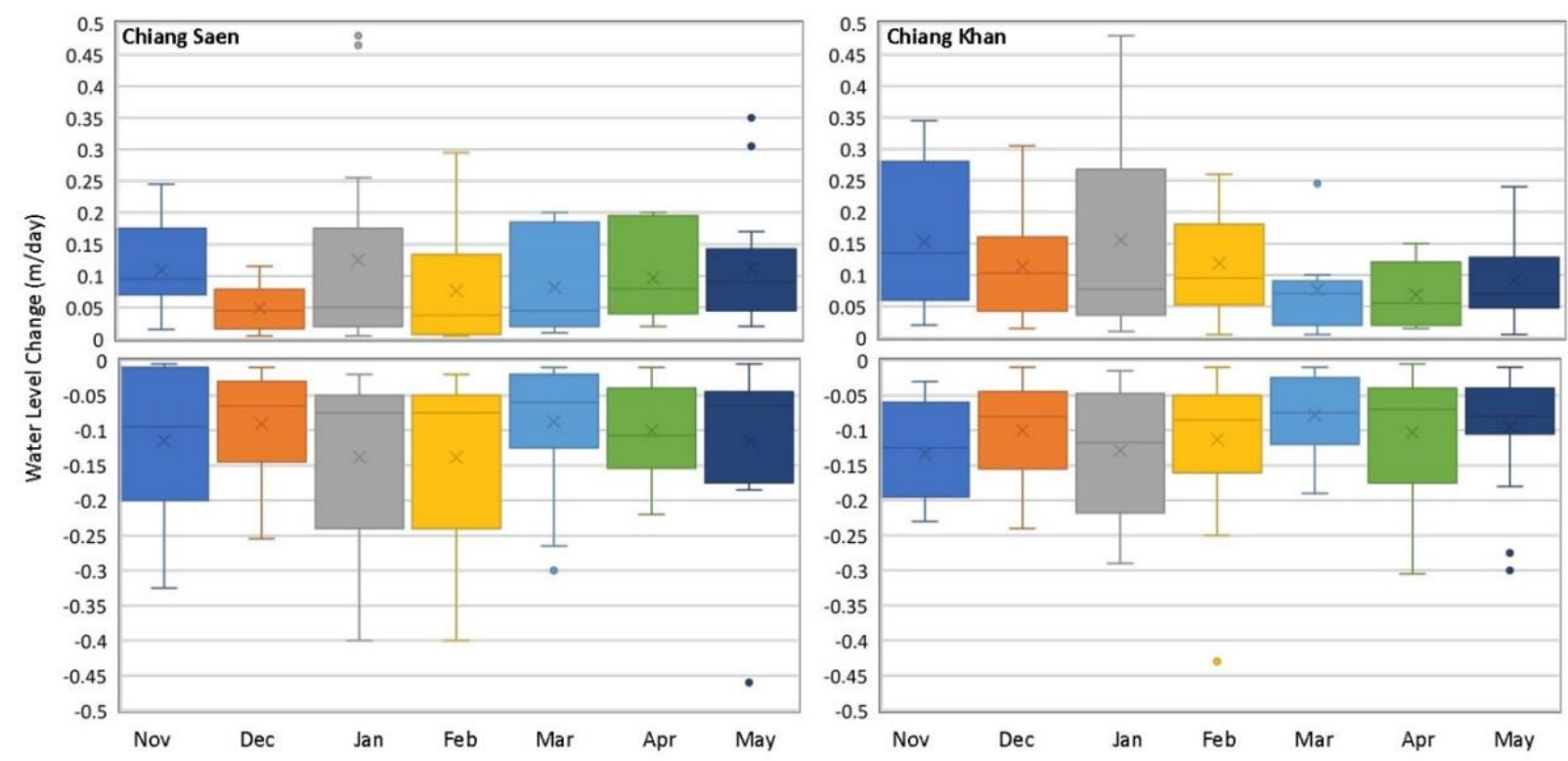

Figure 6. Characteristic of water-level fluctuation at Chiang Saen and Chiang Khan stations for 20202021 dry season

The contribution of water to the LMB from the Lancang River in China to the Mekong mainstream is typically about $25 \%$ of the total dry season flows. However, the inflow of water into the LMB is influenced not only by the Mekong-Lancang cascade, but also by dam operations on the downstream tributaries during the dry season.

\subsection{Water volumes of the Tonle Sap Lake}

The total volume of the reverse flow in the 2020 wet season was only $18.89 \mathrm{~km}^{3}$, or about $44 \%$ of the LTA annual volume of $43 \mathrm{~km}^{3}$ (average condition for 1997-2005). Over the last four years (2018-2021), the volumes of the Tonle Sap Lake were below the LTA (Figure 7). However, despite a lower return flow volume in the 2020 wet season, the maximum water levels in the Lake were similar in 2019 and 2020. In 2019, the Lake reached its maximum level on 1 October. At the end of October 2019, the Tonle Sap Lake experienced much lower than normal water levels. In 2020, water levels continued to rise into October due to the delayed monsoon rain. However, the Tonle Sap Lake's water volume for this dry season is considered a low volume situation compared to its LTA (Figure 7).

Lake levels at the start of the 2021 dry season were consequently lower than normal, although higher than in 2019. The data show that about half of the annual inflow volume into the Tonle Sap Lake originates from the Mekong mainstream. Thus, flow alterations in the mainstream directly impact the Tonle Sap Lake's water levels and hydrology, but these changes can be buffered by the tributary inflows into the Lake. 


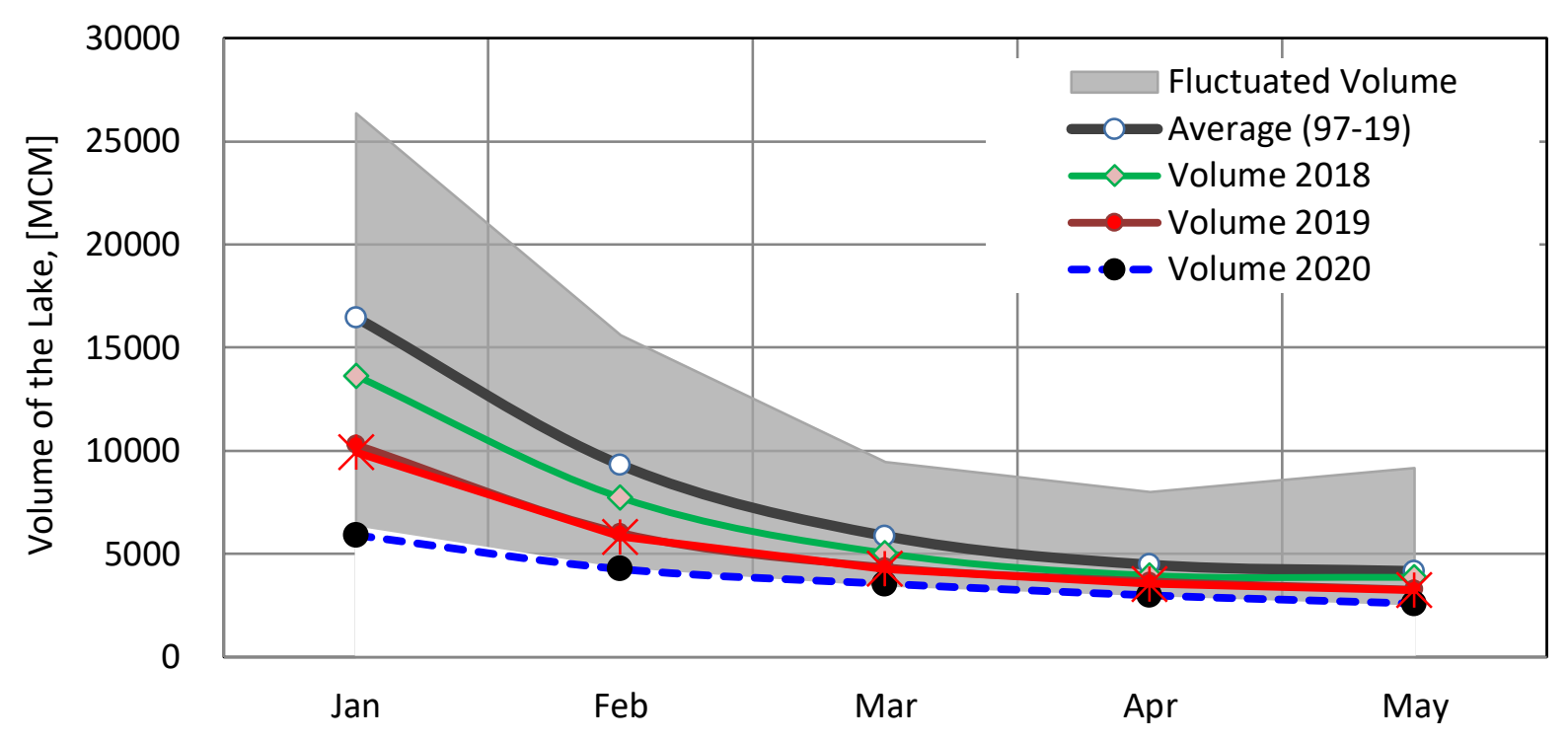

Figure 7. Monthly water storage in the Tonle Sap Lake for the 2021 dry season

\section{Drought monitoring}

The Precipitation Estimation from Remotely Sensed Information using Artificial Neural Networks- (PERSIANN) Cloud Classification System (CCS) observed rainfall data from the Center for Hydrometeorology and Remote Sensing (CHRS) of the University of California at Irvine $(\mathrm{UCI}){ }^{2}$ It emerged that LMB received an average rainfall from November 2020 through February 2021, and a moderate meteorological drought that prevailed over lower part of the region during March 2021, covering some areas in northern Cambodia and the central highland of Viet Nam.

Subsequently, the data show that during April 2021, the LMB received higher-than-average rainfall (Figure 8). Downpours occurred from the north of the LMB down to the central part of Cambodia and in the lower end of the Mekong Delta of Viet Nam. This was the wettest April over the last 18 years on record for the LMB region.

During May 2021, most parts of the LMB were receiving average or above-average rainfall, except some areas in the central part of the region, which received below-average rainfall. The Standardized Precipitation Index (SPI) for May, as shown in Figure 8 (right), using PERSIANNCCS data, reveals moderate and severe meteorological droughts in May, mainly along the Lao PDR/Thailand border area (Nong Khai, Udon Thani, Sakon Nakhon, and Vientiane) as well as the central part of the LMB in Thailand (Khon Khaen, Maha Sarakham, and Roi Et). Although there was an overall rainfall deficit in this area in May 2021, the conditions were not as noticeable for the LMB as a whole, which shows mostly moderately dry conditions with some severely dry patches with a small spatial extent.

\footnotetext{
${ }^{2}$ For more detailed observation, see CHRS (2017).
} 
During the 2021 dry season, March was the driest month, especially in the lower part of the $\mathrm{LMB}$, covering northern Cambodia and the central highlands of Viet Nam. This situation made the three-month meteorological indicator for January-February-March. moderate for the whole basin (Figure 9). Some patches of moderate to severely dry conditions are noted in the northern part of Cambodia and Thailand, covering some areas of Battambang, Banteay Meanchey, Oddar Meanchey, Sa Kaeo, Buriram, Surin, and Si Saket. However, the other 2 threemonth SPIs, including February-March-April, and March-April-May, were relatively wet, specifically the February-March-April due to the higher-than-normal rain in April.
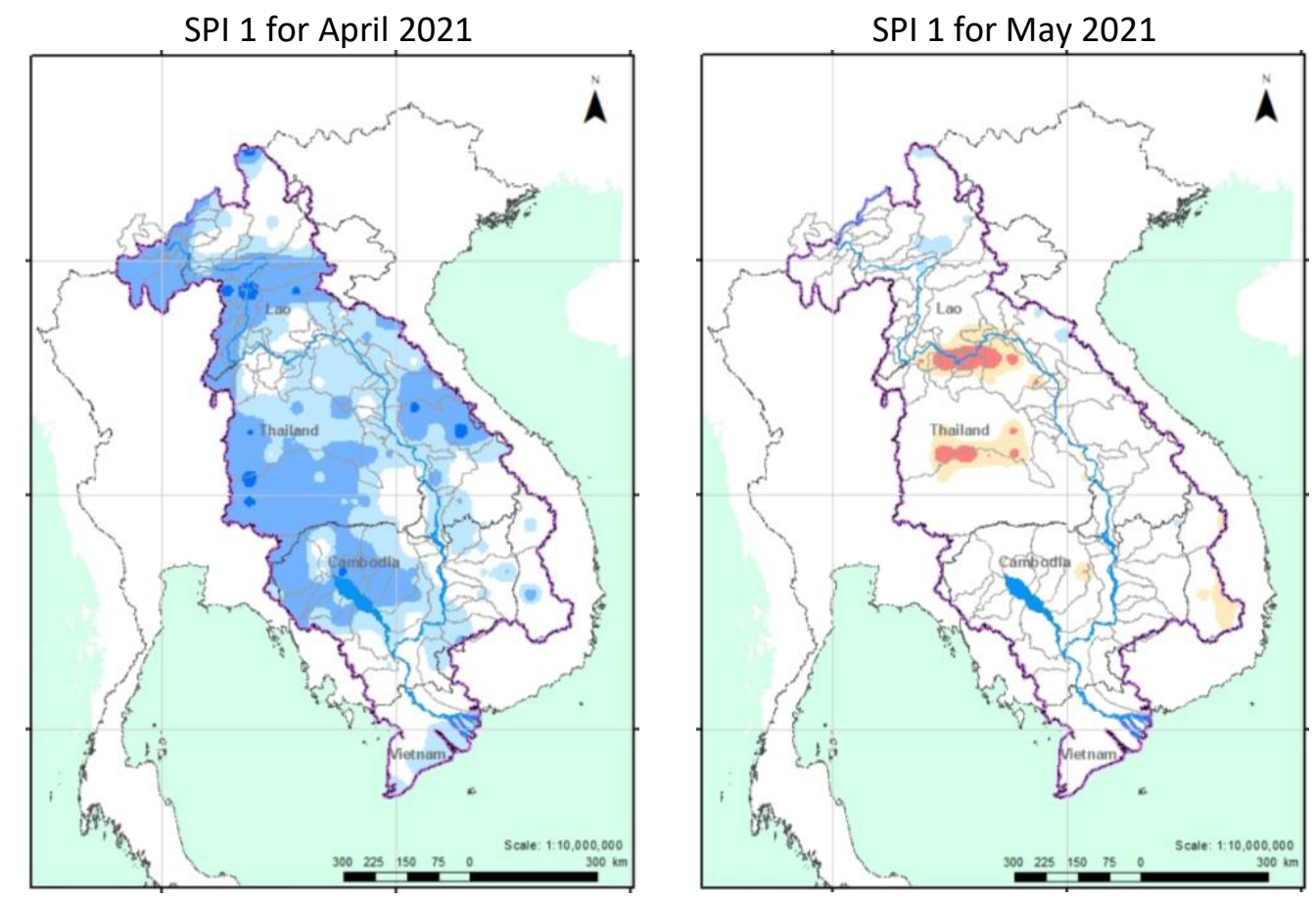

Figure 8. One-month SPI maps for April and May 2021

SPI 3 for Jan.-Feb.-Mar

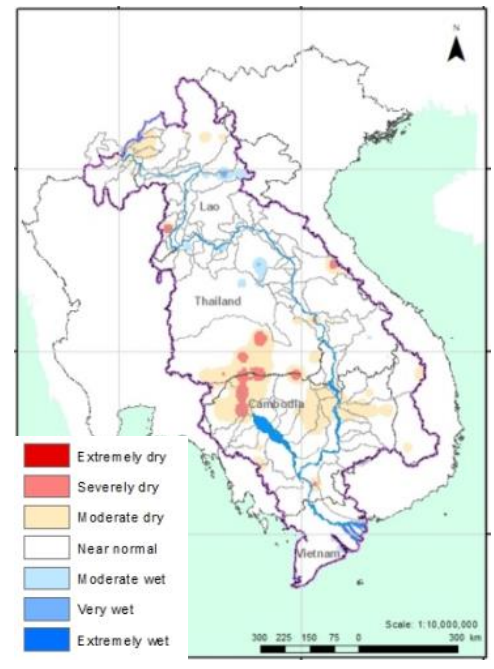

SPI 3 for Feb.-Mar.-Apr

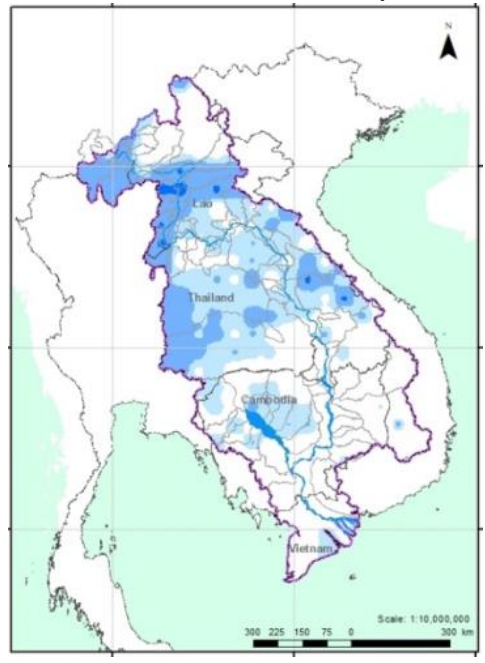

SPI 3 for Mar.-Apr.-May

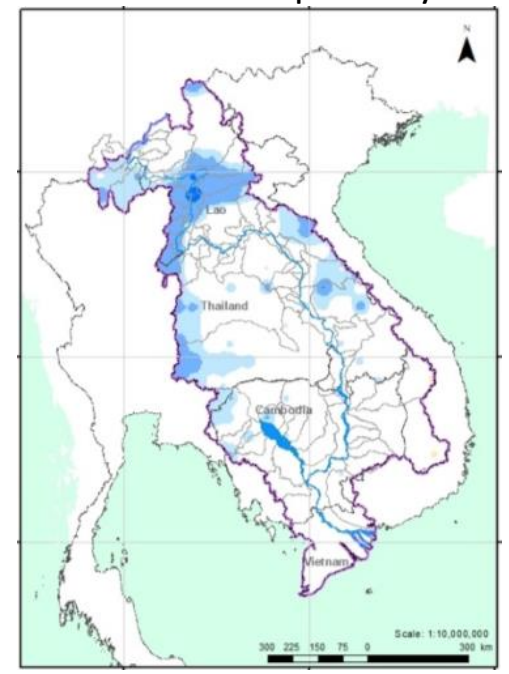

Figure 9. Three-month SPI maps for Jan.-Feb.-Mar (left), Feb.-Mar.-Apr (middle), and Mar.-Apr.-May (right) 2021 


\section{Outlook for the 2021 early wet season}

\subsection{Rainfall outlook}

The National Oceanic and Atmospheric Administration (NOAA) and the European Centre for Medium-Range Weather Forecasts (ECMWF) have forecasted rainfall for June, July, and August 2021 (Figure 10). They show a slight chance of above-normal rain over the Mekong sub-region in June 2021 (the influential southwest Monsoon prevails over LMB together with the lowpressure trough over the middle part of $L M B$ ). But drier than normal conditions are expected in July and August 2021 over parts of the basin. The low-pressure trough will move northward and still prevails over southern China. The southwest Monsoon prevailing over LMB will be mostly weakened. During this period, local hotspots may receive $5 \mathrm{~mm}$ to $20 \mathrm{~mm}$ less rainfall than normal (Figure 10). A gradual return of wetter weather conditions from August 2021 onwards is expected, which will bring some respite. Tropical storms or typhoons will likely influence the LMB during June and August 2021.

Figure $\mathbf{1 1}$ shows the outlook of monthly total rainfall anomaly in June, July and August 2021 over the Asia continent. ${ }^{3}$

\subsection{Prediction of ENSO from May to September 2021}

The El Niño Southern Oscillation (ENSO) modelling for five months prediction (May to Sept) shows that:

- $\quad$ ENSO neutral conditions are likely from June to September (Figure 11). This will likely bring above-normal rainfall over the LMB (Figure 12, left). ${ }^{4}$ However, the temperature will likely be hotter than normal (Figure 12, left). ${ }^{5}$

- A high probability of above-normal temperatures is predicted over Southeast Asia, from the Middle East to the western part of East Asia and East Asia's north-eastern part (Figure 12, right).
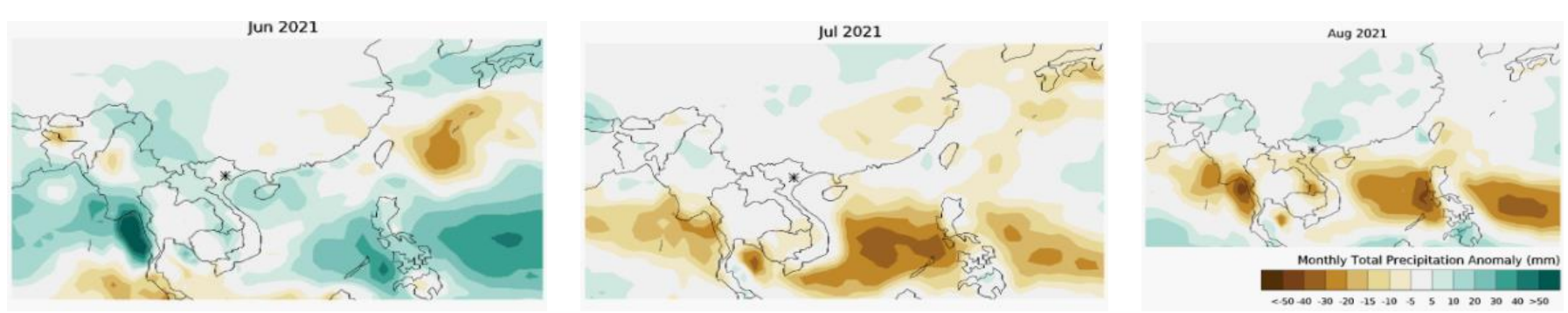

Figure 10. Monthly total precipitation anomaly in June, July and August 2021 in Asia

\footnotetext{
${ }^{3}$ See Meteoblue (2021) for more detail on the seasonal outlook.

${ }^{4}$ For more detailed rainfall forecast, see Tokyo Climate Center/WMO Regional Climate Center in RA II (Asia), Japan Meteorology Agency (JMA, 2021).

${ }^{5}$ For more detailed weather forecast, see (JMA, 2021).
} 


\begin{tabular}{|c|c|c|c|c|c|}
\hline YEAR & MONTH & mean period & & & \\
\hline & MAR & JAN2021-MAY2021 & & 100 & \\
\hline & APR & FEB2021-JUN2021 & & & 50 \\
\hline & MAY & MAR2021-JUL2021 & & & 20 \\
\hline 2021 & JUN & APR2021-AUG2021 & 10 & 80 & 10 \\
\hline & JUL & MAY2021-SEP2021 & 20 & 70 & 10 \\
\hline & AUG & JUN2021-OCT2021 & 20 & 70 & 10 \\
\hline & SEP & JUL2021-NOV2021 & 20 & 70 & 10 \\
\hline & & & & $\begin{array}{l}\text { ENS } \\
\text { neutr }\end{array}$ & \\
\hline
\end{tabular}

Figure 11. Outlook of the SST deviation and ENSO forecast probabilities up to September 2021
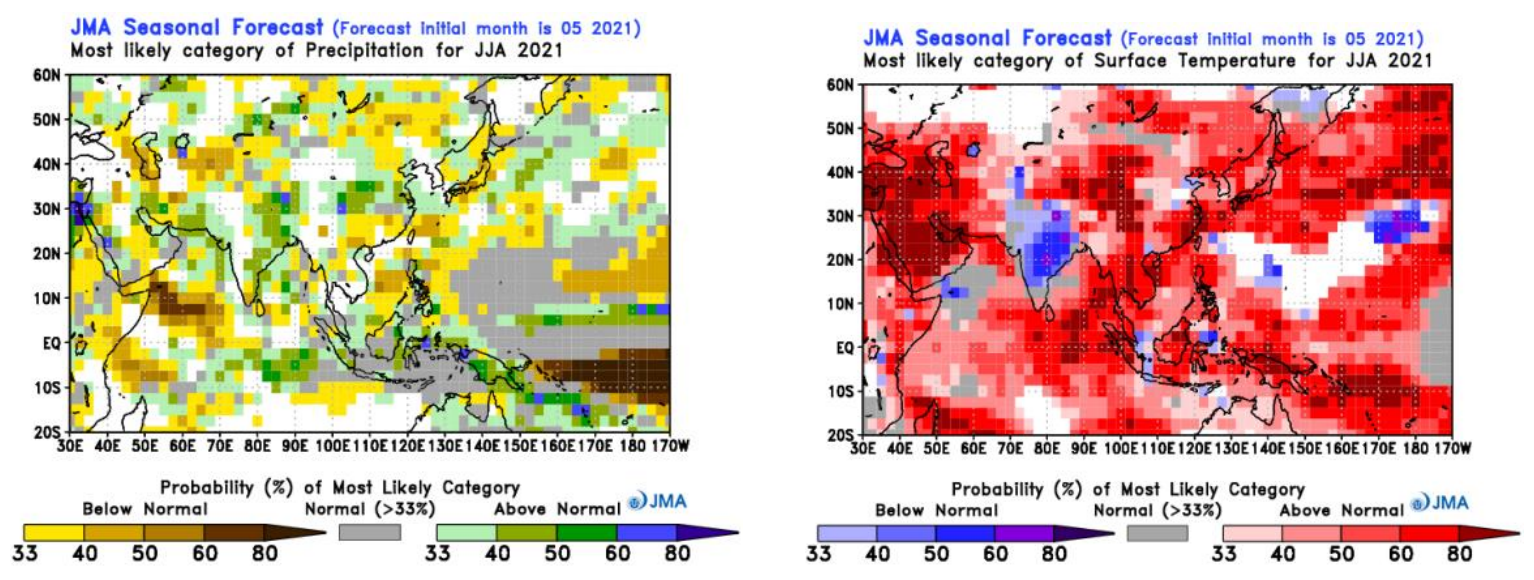

Figure 12. The early wet season (June, July, and August) forecast of precipitation (left) and temperature (right)

\subsection{Drought forecasting}

The MRC Drought Forecasting and Early Warning System (DFEWS) uses the ensemble model, which averages all scenarios in the North America Multi-Model Ensemble (NMME). The downscaled 5-km data are used to carry out monthly forecasts across the LMB. The global-scale rainfall prediction is used to assess the rain distribution for the coming months. Figure 13 shows the ensemble mean anomaly in precipitation ( $\mathrm{mm} /$ day) from June to September 2021 produced by NMME.

The global ensemble prediction model forecasts that June is likely to bring average to aboveaverage rainfall in the entire $L M B$ region. The central part of the $L M B$ and the eastern part of Cambodia is forecasted to be the wettest areas. In July, Cambodia, the Central Highland of Viet $\mathrm{Nam}$, and southern Lao PDR may receive less rainfall than normal. Most of the LMB region is forecast to experience a meteorological drought in August. Finally, the lower part of the LMB covering eastern Cambodia and parts of Viet Nam is likely to receive below-average rainfall in September Figure 13. 


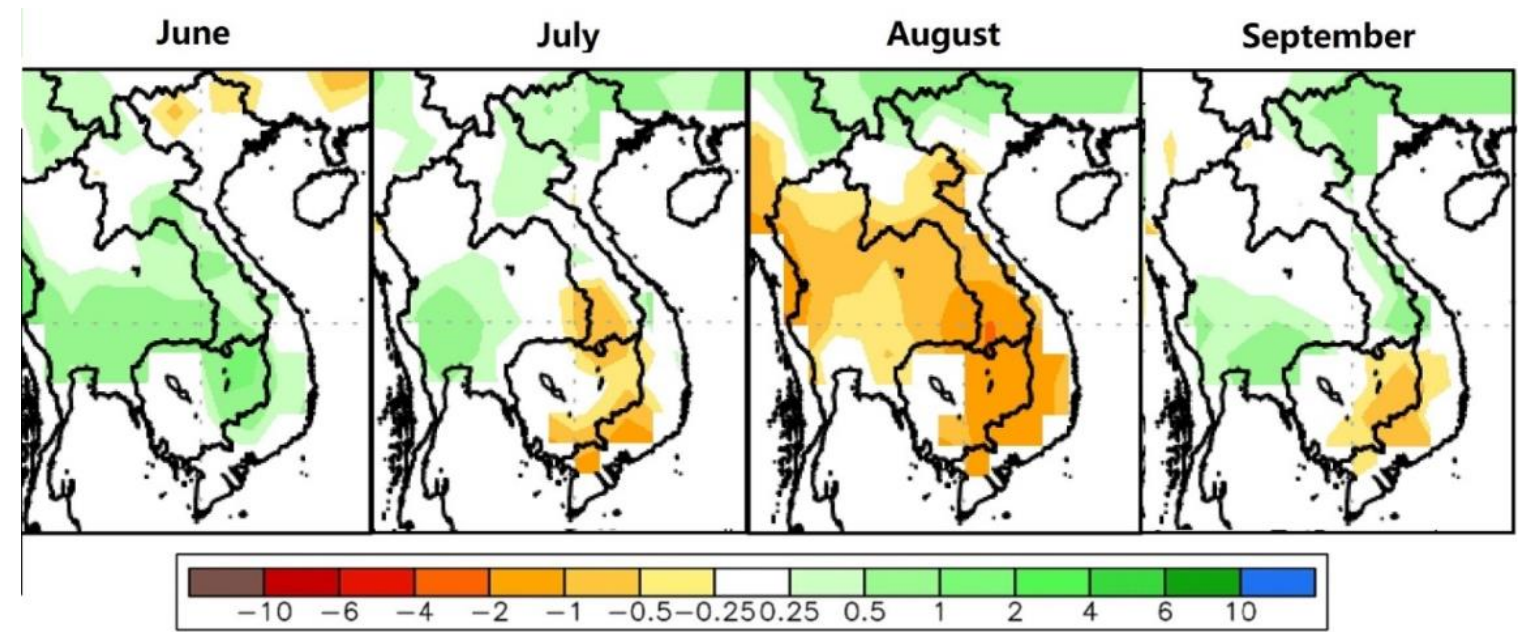

Figure 13. The Standardized Precipitation Index forecast for June, July, August and September 2021

Based on the downscaled Combined Drought Index (CDI) forecasts, ${ }^{6}$ the LMB is more likely to be wet in the west and extremely dry around Vientiane and Nong Khai in June 2021 (Figure 14, left). The forecasts also indicate that the northern and south-eastern ( $3 S$ area) parts of the LMB may experience some severe meteorological droughts in July (covering Chiang Rai, Bokeo, Luang Namtha, Oudomxay, Phongsaly, Vientiane, Xaysomboun, Borikhamxay, Nong Khai, Saravane, Sekong, Champasak, Attapeu, Kon Tum, and Gia Lai).
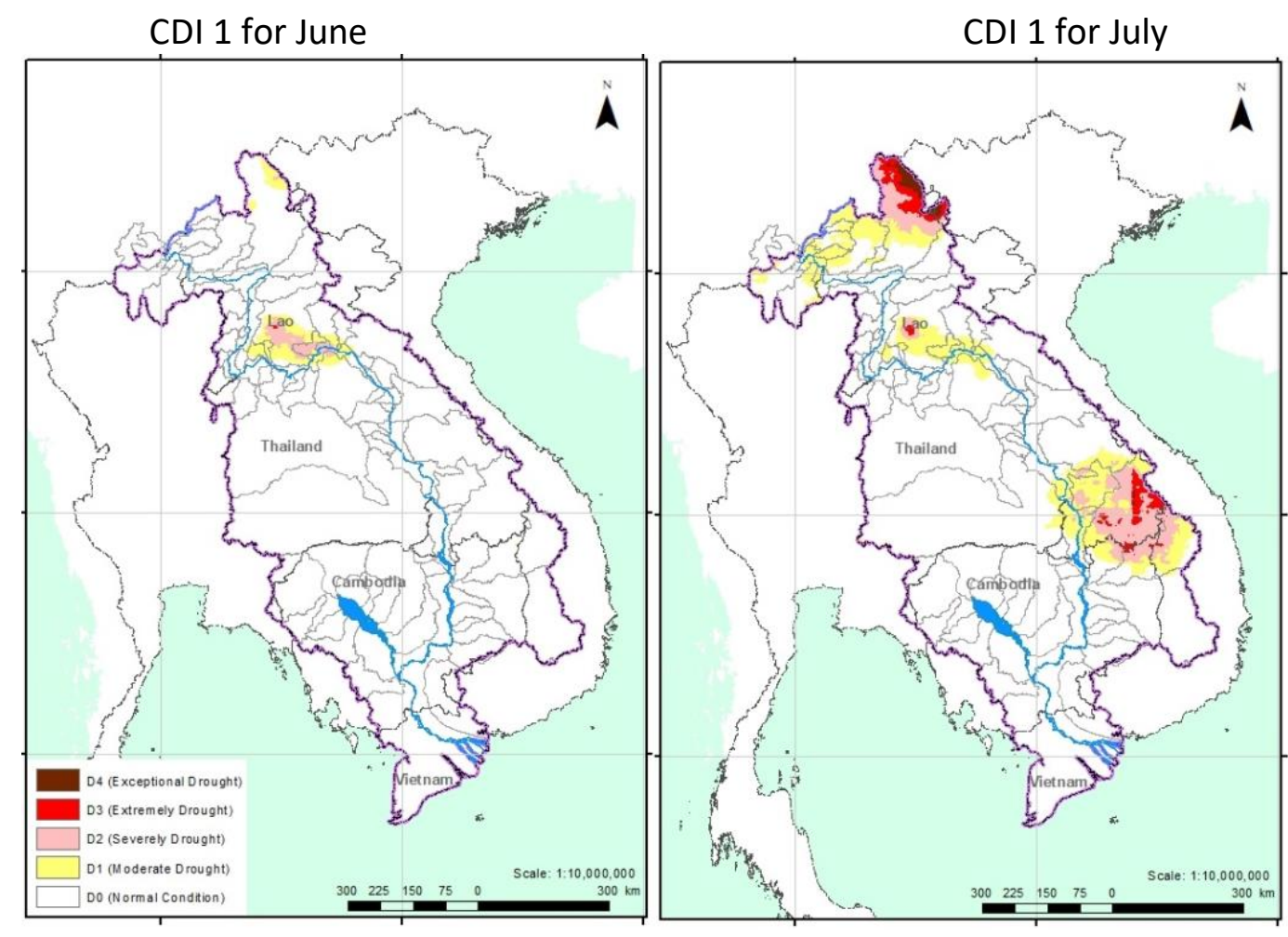

Figure 14. The forecasted Combined Drought Index (CDI) for June and July 2021

\footnotetext{
${ }^{6}$ See the MRC's weekly drought summary for more detail (MRC, 2021a).
} 


\section{Impacts}

The main feature of the 2021 dry season was the fluctuation of water levels in the Mekong mainstream just downstream of China, and the low water volume stored in the Tonle Sap Lake. The potential impacts of these phenomena are outlined below.

Along some stretches of the mainstream, water levels fluctuated from $0.3 \mathrm{~m}$ to $1 \mathrm{~m}$ over a few days. This may have affected activities along the riverfronts and banks. The fluctuations were apparently caused by the operation of the upstream hydropower dams. The combined operations of the hydropower project on the Lancang cascade caused water-level fluctuations in the upper mainstream at Chiang Saen. But it is not known whether the Jinghong dam was used to attenuate some of the rapid upstream water-level fluctuations due to upstream hydropeaking operations in China. The Xayaburi dam, which had just started operations, would similarly contribute to small fluctuations that would be noticeable at Chiang Khan, Vientiane, and Nongkhai. But water-level fluctuations would be negligible over this reach. The maximum rate of water-level change is less than $5 \mathrm{~cm} /$ hour, which is considered not significant according to the MRC Hydropower Mitigation Guideline (MRC, 2020).

Overall, flows in the Mekong in the first five months of 2021 were higher than the LTA. This results from the operations of the hydropower projects that store water in the wet season and release it in the dry season to provide more assured power outputs. However, there is some carryover at the start of the dry season since the hydropower projects are holding back some of the last flows of the wet season, and again towards the start of the wet season as the early rain is held back to re-fill the reservoirs on the Lancang and LMB tributaries. Nonetheless, except for December 2020, flows in the Mekong mainstream were within the thresholds outlined in the PMFM.

Most of Cambodia's population relies on the natural resources supported by the Tonle Sap Lake system for their livelihoods. The system's hydrology is characterized by the unique seasonal flows of the Tonle Sap River, connecting to the Mekong River. The lower flow in the Mekong in the 2019 and 2020 wet seasons decreased return flows and the volume and seasonally flooded area of the Tonle Sap Lake. This will have adverse impacts on agricultural production and ecological balance, and reduce nutrient-rich sediment mobilization and transportation, and decrease household fish catch in the Tonle Sap Lake area.

Similarly, recession agriculture may be affected. Decreasing the amount of freshwater flowing into the Delta increases saltwater intrusion into the Delta during the dry season. But as dry season flows are generally higher than normal, this is less pronounced for most of the dry season. In the early part of the dry season, flows into the Delta are also influenced by the previous wet season levels in the Tonle Sap Lake and longer-term tidal cycles. 


\section{Conclusion and recommendations}

\subsection{Conclusion}

During the 2020/2021 transition period, the water levels of the Mekong River in 2020 were lower than their LTAs for all monitoring stations. Like many parts of the world, the Mekong region was affected by the prolonged $E I$ Niño phenomenon, which usually causes extreme heat and lower rainfall. The hydropower operations on the Lancang and tributaries then raised flows above the LTA for the rest of the dry season.

The April-May rain was, in places, the highest recorded volumes for this period over the last 18 years. This was particularly evident over the middle part of the LMB areas of Thailand and northern Cambodia. The northern and southern Lao PDR, 3S areas, and the Centrals Highland of Viet Nam experienced lower rainfall during May. The high-pressure air mass, which had prevailed over the Mekong region since November 2020, started to weaken in early April. The thunderstorms that occurred in April and May caused higher rainfall in various locations in LMB. In some areas, intense, heavy rainfall could have been possible. The rainfall did not contribute significantly to flows due to dry soil surfaces that absorb more of the rainfall.

Compared to the LTAs, the water levels in the LMB region were higher for this 2021 dry season (especially in February to May 2021) due partly to above-normal flows from the Lancang River. The above-average water levels were generally observed from Chiang Saen in Thailand to Paksane in Lao PDR. In the Mekong Delta in Viet Nam at Tan Chau and Chau Doc, the water levels fluctuated due to tidal conditions.

The flows at Jinghong hydrological station experienced rapid fluctuations in water levels. The water level at Chiang Saen fluctuated less since it is about $330 \mathrm{~km}$ from Jinghong station, and the river is wider at this point. The water levels at Chiang Khan, Vientiane and Nong Khai are affected by the operation of the Lancang Cascade and, to a lesser extent, the Xayaburi Hydropower Operations. Since these stations are further downstream, the fluctuations become smoother. The maximum rate of water-level fluctuation is less than $0.5 \mathrm{~m} /$ day, which is considered insignificant according to the MRC Hydropower Mitigation Guideline (MRC, 2020). However, it should be noted that this is an initial assessment of the river water-level fluctuation at selected sites along the river. It was not possible to analyse the fluctuations between the dam sites and these stations due to problems with the monitoring stations. Some stations were recently installed closer to the dam site, but they are not fully operational. The data are also under verification and are not sufficient to analyse the water-level fluctuation for this dry season.

The Tonle Sap Lake experienced much lower than normal water levels. The water volumes of the Lake were higher at the start of the 2021 dry season than in 2020. But this appears to be due to the delayed monsoon rain in the wet season. The Lake's water volume for this dry season is considered low compared to its LTA level. 
The overall drought conditions during the dry season 2021 were mostly normal, and the whole region did not face any significant threat. However, the meteorological indicator shows some moderate and severe dryness in the lower part of the LMB, covering some areas of the northern part of Cambodia and Central Highland of Viet Nam. These areas received below-average total rainfall in March 2021. The climate forecasts for June, July and August indicate that the LMB is likely to receive above-average rainfall in June and August, but below-average rainfall in July.

The Tonle Sap Lake low levels in May will continue into June and July. The reverse flow to Tonle Sap Lake, which usually starts in mid-May, is expected to follow the previous year's pattern, being delayed. But this is still subject to actual rainfall over LMB from June to October 2021.

\subsection{Recommendations}

Transparent and timely data and information sharing remain important. The MRC Secretariat continues to identify additional key data and information necessary for water resource management and development. Additional efforts in data and information sharing and exchange by the MRC MCs and Dialogue Partners are highly encouraged.

It is recommended that a more detailed study be carried out on the pattern of water-level changes using the newly installed stations at Xiengkok upstream of Chiang Saen and Ban Pakhoung downstream of Xayaburi dam.

The possibility of regulating dry season flows in December by releases from storage should be explored and balanced against the risks to assured power production. 


\section{References}

CHRS. (2017). Satellite precipitation: The PERSIANN System. Retrieved on 28 May 2021 from https://chrs.web.uci.edu/SP_activities00.php

JMA. (2021). Probabilistic forecast (three-month prediction). Retrieved on 28 May 2021 from https://bit.ly/3drseAm

Meteoblue. (2021). Seasonal outlook. Retrieved on 7 June 2021 from https://bit.ly/3vZbOAI

MRC. (2006). Procedures for the Maintenance of Flows on the Mainstream. Vientiane: MRC Secretariat. Available at https://bit.ly/3v7HyJ2

MRC. (2020). The MRC Hydropower Mitigation Guidelines: Guidelines for hydropower environmental impact mitigation and risk management in the Lower Mekong mainstream and tributaries (MRC Technical Guideline Series, Vol. 3). Vientiane: MRC Secretariat. Available at https://bit.ly/2UbkZpk

MRC. (2021a). Drought early warning in Lower Mekong Basin: Weekly drought summy. Retrieved on 28 May 2021 from http://droughtforecast.mrcmekong.org/maps

MRC. (2021b). Procedures for the Maintenance of Flows on the Mainstream. Retrieved on 28 May 2021 from https://pmfm.mrcmekong.org 
ISSN: 1683-1489

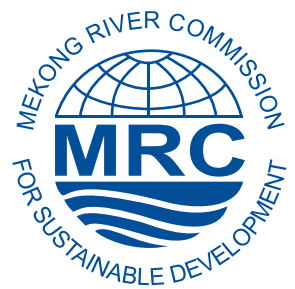

Mekong River Commission Secretariat

P. O. Box 6101, 184 Fa Ngoum Road, Unit 18 Ban Sithane Neua,

Sikhottabong District, Vientiane 01000, Lao PDR

Tel: +85621263 263. Fax: +85621263264

ww.mrcmekong.org

(C) Mekong River Commission 2021 